\title{
USING MARKETING ANALYTICS TO UNDERSTAND CONSUMER LIFESTYLE FOR HAIR SALONS IN DELHI AND KOLKATA
}

\author{
Prof. Sandeep Bhattacharjee \\ Assistant Professor, Amity School of Business, \\ Amity University, Kolkata \\ Dr Shivani Raheja \\ Assistant Professor, \\ Department of B.A(H) Business Economics, \\ Aryabhatta College, University of Delhi.
}

\begin{abstract}
The world is undergoing change and change seems to take place everywhere. Even, the less talked industries are gaining momentum including the hair salon industry. In this research paper, we have tried to investigate the usage of hair salon among consumers in two major cities namely Delhi and Kolkata. This research primarily focuses on a mixed sample of both students and working population. A primary investigation was also conducted to identify different facts which helped in designing of the introduction part along with literature review. Later data analysis was conducted on data collected from 114 samples through online questionnaire involving both structured and unstructured questions. Statistical methods of descriptive analysis, discrimination analysis and cross tabulation (with Cramer $V$ calculation for association test) were used to test the strength of association between prime factors based on gender. The results of this research can be useful for researchers, academicians and others in this field who can learn and benefit to a great extent.
\end{abstract}

Key words: consumer, gender, hair salons, satisfaction.

\section{INTRODUCTION}

Historically, barbershops and beauty salons have been claimed as admirable venues for discussion on health information and growth of community awareness.

According to recent research, beauty is currently a USD 10 billion plus industry in Bangladesh, providing employment to an estimated 100,000 women (Akter 2009). There are more than thousands of beauty-care service providers or beauty parlors/salons that have arisen all over the in Bangladesh in the last decade (Akter 2008, Akter 2009)1,2 as the importance of being beautiful has been rapidly increasing.

Even at social level, physical beauty for both males and females is considered as an advantage, as being beautiful gives a person much more confidence (Young 2011). It has even been shown that being attractive can give individuals an increase in the chance of getting partners or being married (Young 2011)16. Also, many private jobs requires being physically more attractive for candidates with almost same qualifications that seems an important fact for selection or getting hired for the same job (Gilmore, Beehr \& Love 1986)4 .

Further, the more beautiful people are much likely to be promoted or elevated to senior positions and are also likely to be paid more (Young 2011)16.

According to the author, like any other service industry in Asian counties, quality of service is considered as the most important factor for the beauty-care service industry. Many other relevant study based evidences show that when consumer's opinion of quality of service are positive, the behavioral pattern becomes more favorable, and fortify their connection with the organization (Zeithaml \& Bitner 2003)17. Alternatively, when service-quality considerations are negative, the customers' behavioral objectives become highly unfavorable (Kouthouris \& Alexandris 2005)7. 


\section{Yinternational Research Journa!}

p-ISSN 2202-2821 e-ISSN 1839-6518 (Australian ISSN Agency)

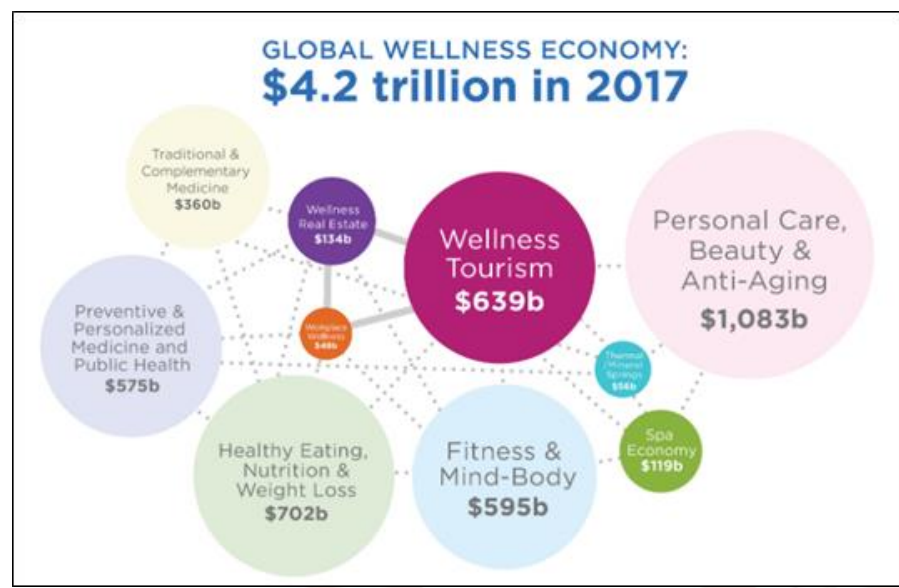

Figure 1. Global wellness report, 2017

(Source: https://globalwellnessinstitute.org/wpcontent/uploads/2018/10/GlobalWellnessEconomy2017 bubbl echart.jpg)

\section{II.LITERATURE REVIEW}

In the last decade or so, the beauty care services industry in India has achieved momentum owing to many reasons that includes modern Indian's acceptance of western trends and fashion and that necessitates providing more importance to grooming services.

The recent trends in growing disposable income of middle class with women in particular, growing exposure of media and increasing consciousness about brands are simultaneously powering this industry into manifolds. It has been observed that customers are increasingly their perception is positive for fresh and different products. (Kaur Amanpreet, 2014) ${ }^{6}$.

For understanding the facts we must try to identify the concept of customer satisfaction that was mainly introduced in the domain of marketing by Cardozo in the year $1965^{3}$. Of later, this concept has been extensively studied since the existence of all businesses relies greatly on customer satisfaction. Customer satisfaction is derived from the needs and wants of customers.

As per the different research interpretations by authors and researchers, it can be considered as a feeling that is a result of the process of evaluation by the customer with respect to what has been received against somewhat that may have been expected from a some product or service or a combination of them. In other words of description, satisfaction is the consumer's assessment of a product or service in consideration matched or unmatched needs and expectations from product or services procured at a negotiated price . (Bitner \& Zeithaml, 2003) ${ }^{\mathbf{1 7}}$.
Vol. 10 No. 022020

82801002202006

Another study ascertains of the fact that high service quality leading to high levels of customer satisfaction may propel high customer loyalty. (Kumar, Kee and Manshor, 2009) ${ }^{8}$.

One of the practical realm fact is related to the existence of beauty salons and barbershops that can be found in almost all communities that includes small and large, urban, rural and suburban localities. These beauty and hair saloons have been trying very hard to gather the attention of customers through better services and in the process reaching and engaging those who may not be communicated through traditional settings. In general, these beauty salons or barbershops may be thought of as a "secure" space where more attention can be provided on individual appearance, be informed of community news in addition to socialization. Another interesting underlying factor can be the exclusive trust based relationship that can exists between the customer and barber or stylist. As perceived historically, salons and barbershops have been found to be catalytically active to the economic, political, and social development of their communities.

In terms of service delivery, worldwide trend indicates that service quality was ideated in the 1880 s, when many organizations started to comprehend that continuing viable advantage is not assured by a quality product and must be supplemented by service quality (van der Wal, Pampallis \& Bond 2002) ${ }^{\mathbf{1 3}}$. They realized that quality of services can be the differentiation between success chances and failure reasons for both service and manufacturing firms (Gupta, McDaniel \& Herath 2005) ${ }^{\mathbf{5}}$. In such category, service quality, customer satisfaction and customer value are the major concerns in both manufacturing and service organizations (Wang, Lo \& Yang 2004) ${ }^{\mathbf{1 4}}$, due to the fact that many researchers claimed that service quality can actually lead to a real and long lasting competitive advantage (Moore 1987, Lewis 1989). Also, factors such as customer satisfaction is considered as one of the critical result of marketing hussle (Oliver 1980, Mick \& Fournier 1999) ${ }^{10}$. As revealed by Zeithmal and Bitner (2003), "satisfaction is the consumer fulfillment response. It can be revered as an opinion that a product or service factor, or the product or service itself, shows a delightful level of consumption-related realization" (p. 86). One of the key findings by Kumar, Kee and Manshor (2009)states that high quality of service can lead to high customer satisfaction and improves the chances of customer loyalty. Thus customer satisfaction is the outcome of service quality (Parasuraman, Zeithaml \& Berry 1988) ${ }^{11}$

In terms of the hair and beauty industry, very less consideration with ignorance has existed considering many non organized entities in the economic sector due to lack of 


\section{Yinternational Research Journa!}

p-ISSN 2202-2821 e-ISSN 1839-6518 (Australian ISSN Agency)

professionalism and believing in the sense that such consumer activities is related to the supplementary source of income. Many research studies highlighted that school dropouts and with less education have opted for careers in such industry (Stephanie, 2008) ${ }^{\mathbf{1 8}}$. But it must be noted that, hair salons also faced distinctive challenges such as lack of quality access to mandatory information, non accessibility of credit, inferior or less market research and short of of market for their products.

In spite of these challenges, they have actually lead to provision of noteworthy role in generating opportunities of employment and livelihood.

As observed in the salon business, a very high rate of staff turnover has been witnessed since decades. Winnie (2005) 15 stated that legal and human resource management challenges exist since most salon employees actually never agrees to with employment contracts and along with the fact that mostly salon owners and managers have not emphasized on really motivating their employees. Another fact often neglected has been the customer migration with frequent staff migration to other saloons This is one of the factors that most saloon owners seem to have almost no control and may lead to potential client loss and suffer losses. Winnie (2005) ${ }^{15}$

The above mentioned facts lead to the exploration of the reasons of the consumer preferences that has led us to construct the research objectives as such:

a. To identify the main demographics of the samples included in survey.

b. To identify different salon related factors in hair salon industry.

c. To compare the affects of hair salon usage related phenomenon on genders.

d. To provide useful suggestions for improving hair saloons for customer satisfaction.

\section{RESEARCH METHODOLOGY}

In this research paper, our intention was to identify and understand the different aspects of consume preferences for hair salons in Delhi, Kolkata and adjoining areas. To understand this, we have collected secondary data from various published sources such as journals, published reports. Some tables and figures have also been used based on secondary data sources.

In order to verify established facts, we have also undertaken primary research where 114 samples were asked to fill the online questionnaire related to usage of salon services in hair
Vol. 10 No. 022020

82801002202006

salon industry segment. Questionnaires included both open ended and closed ended questions. The data collected henceforth, was sorted systematically, arranged and analyzed using statistical tools by using Microsoft excel and SPSS VERSION 17.The trends were also collected from reputed sources and were acknowledged. A preliminary investigation helped in construction of the literature review part and observation technique was used to build the periphery of discussion and analysis.

\section{DATA ANALYSIS AND DISCUSSION}

\section{DESCRIPTIVE DEMOGRAPHIC ANALYSIS:}

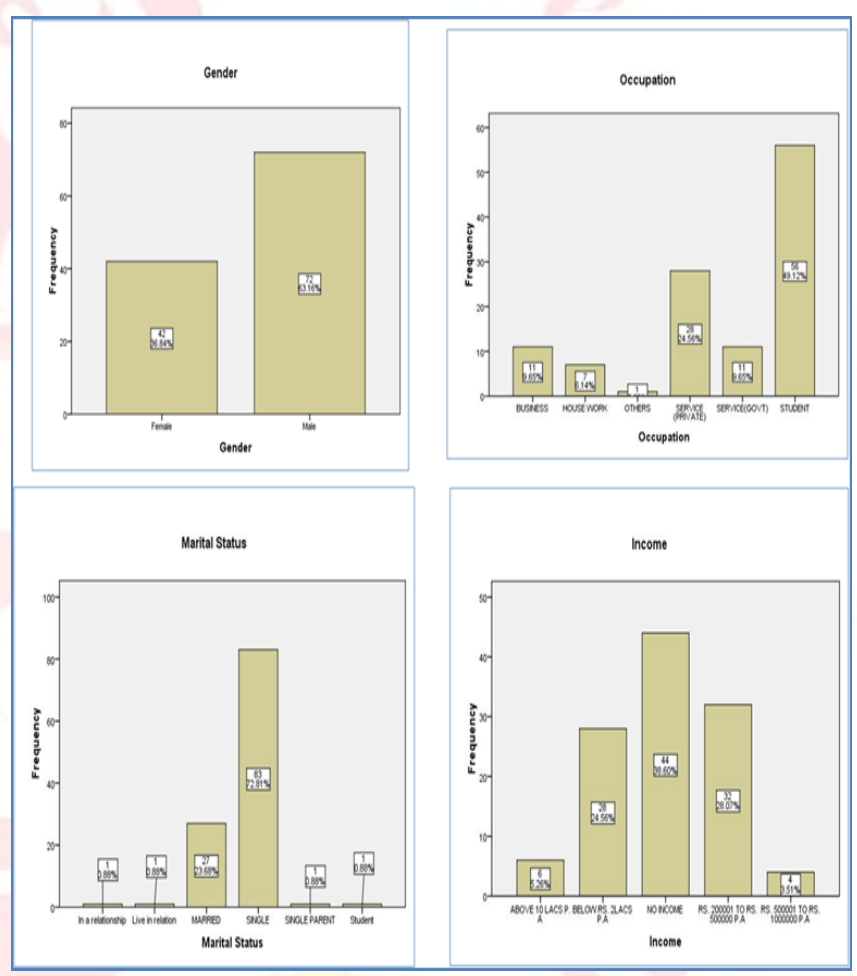

Figure 2. Demographic statistics of samples for hair salons

( Source : Author analysis)

As seen in Figure 2, in terms of gender there were $63.16 \%$ males and $36.84 \%$ females who participated in the hair salon survey.

It was also observed that a higher proportion of students $(49.12 \%)$ while the rest was non students or working samples both in private, public, business and others.

This also gave a good representation of samples from population mix. While most of them were singles( $72.81 \%)$, $23.68 \%$ were married.

The income earning samples were nearly $61.40 \%$ which also shows inclination of earning samples towards hair salons. 


\section{DISCRIMINANT REDUCTION):}

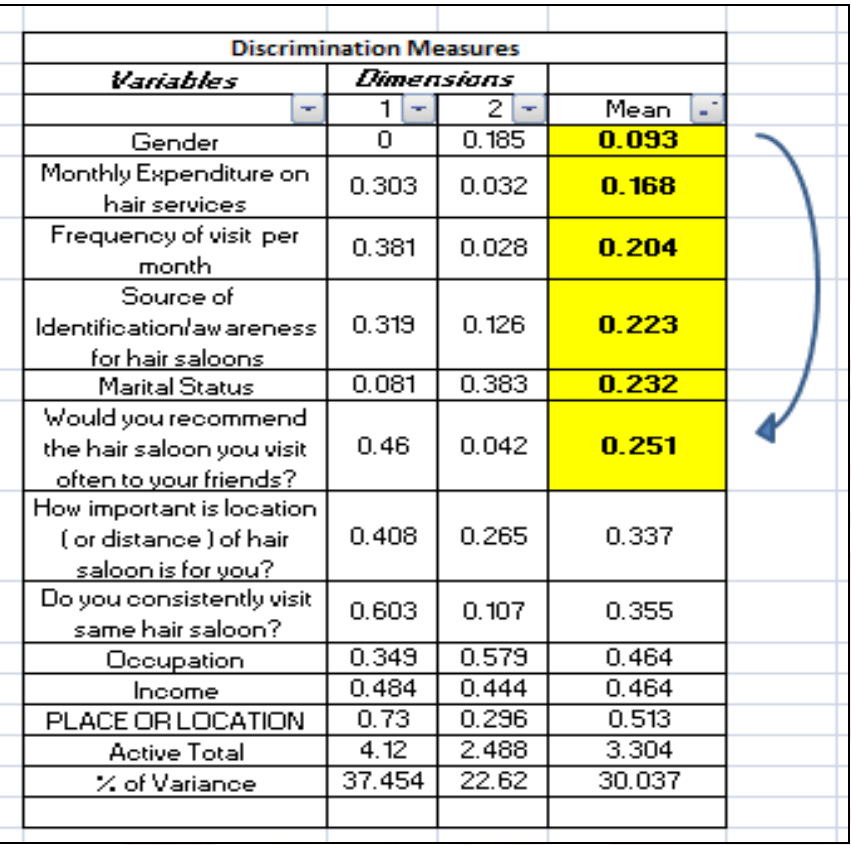

Table 1. Discriminant analysis of prime factors of for consumers ( Source : Author analysis)

As seen in table 1, monthly expenditures on salon with minimum cluster mean of 0.168 is considered an important factor for samples in salon industry. Another, vital factor that affects the environment was frequency of visits per month by samples (cluster mean= 0.204). In salon environment, source of identification/ awareness of salon was also felt as an important factor affecting different genders of samples.

As seen in figure 3, the distance between recommendation and the marital status is very large which points out that these two may not be correlated to each other.

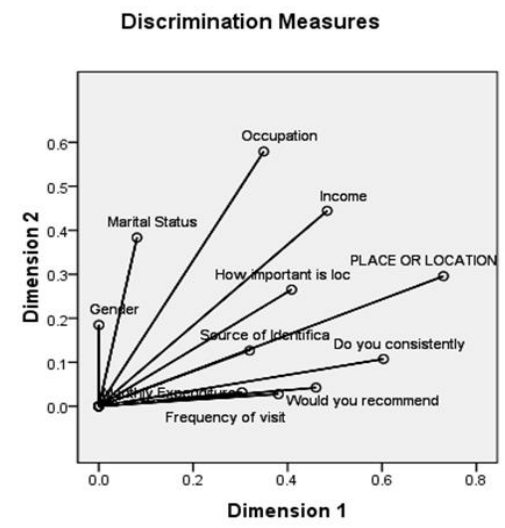

Variable Principal Normalization.

Figure 3. Multi correspondence variable analysis using optimal scaling (Data reduction) of environmental factors

( Source : Author analysis)

\section{CROSS TABULATION ANALYSIS :}

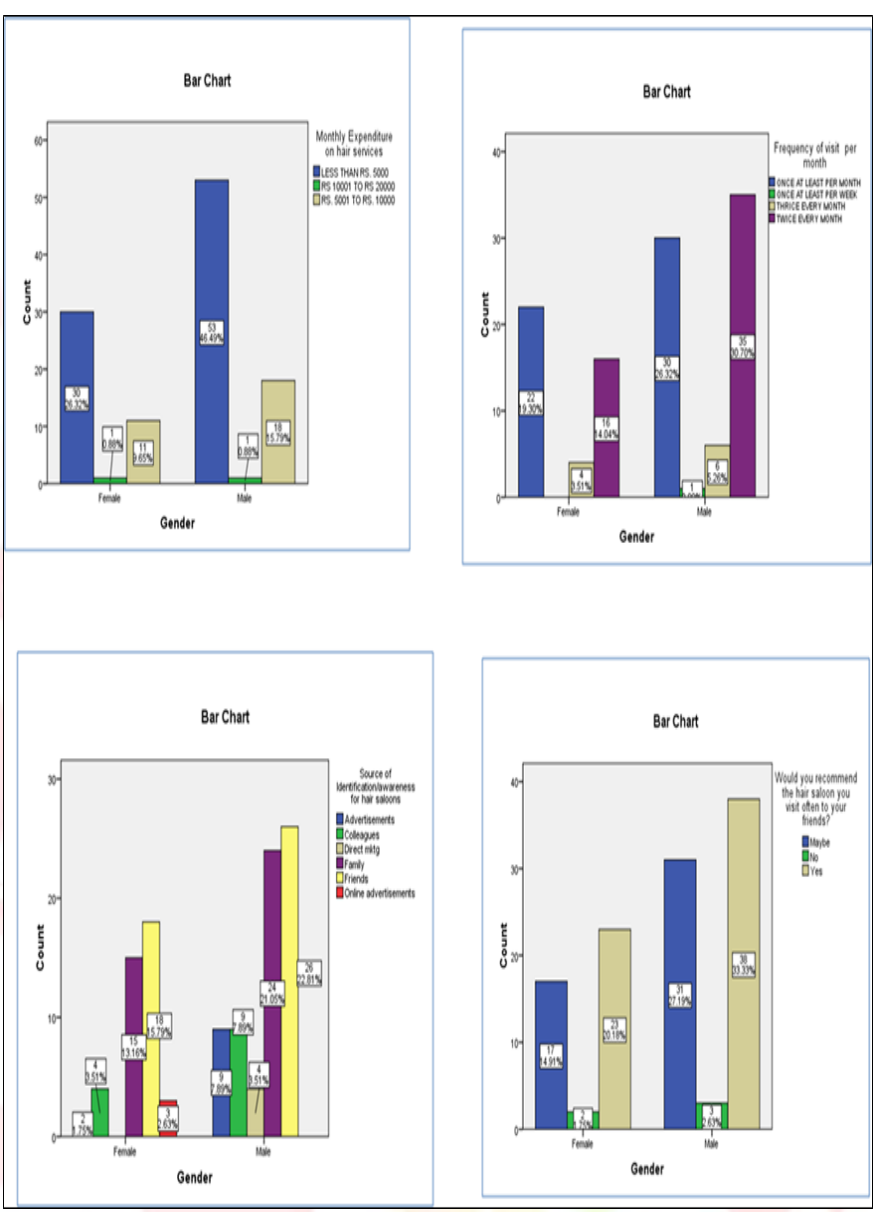

Figure 4. Cross tabulation of Gender with prime factors (Source : Author analysis)

As seen in Figure 4, gender has been related to monthly expenditures on hair salons, frequency of visit per month, source of identification/awareness for hair salons, and recommendation of hair salons.

It was observed that $46.49 \%$ males and $26.32 \%$ female's monthly expenditures were less than Rs 5000. Also, 30.70\% males and $14.04 \%$ females revealed that they visit hair salons twice excluding $26.32 \%$ males and $19.30 \%$ females who visited salons at least once a month.

Some samples also reflected their source of awareness of hair salons as friends ( $22.81 \%$ males and $15.79 \%$ females) and families ( $21.05 \%$ males and $13.16 \%$ females).

More than $50 \%$ of samples agreed for further recommendation of hair salons ( $20.18 \%$ females and $33.33 \%$ males) while around $42 \%$ of samples (14.91\% females and $27.19 \%$ males) reflected some chance of possible recommendation of hair salons to their friends. 


\section{V.FINDINGS \& CONCLUSIONS}

As seen above, the findings can be summarized as followed:

1. Around $63.16 \%$ males and $36.84 \%$ females had participated in the hair salon survey. A considerable balanced number of samples with students ( $49.12 \%$ ) and rest were working professionals. Therefore, a balanced sample response has been obtained from research. ( see figure 2)

2. Factor reduction through discriminant analysis, indicates important factors such as gender, monthly expenditures on salons, frequency of visits per month, source of identification/ awareness of salon that needs to be correlated. ( see table 1, figure 3 ).

3. 3.Cross tabulation results reflect both males and females ( 46 and $22 \%$ approx) still spending less than Rs 5000 per month which indicates of the future possibilities of more expenditure provided facilities are improved. (See figure 4.)

4. Both families and friends play a significant role in hair salon visit decision of samples involved in the research survey.

5. Word of mouth recommendations have also been noticed with more than $50 \%$ preferring to recommend their salon preferences to friends and another $42 \%$ approx hinting of possible recommendations.

Therefore, from the above findings we can conclude that $\mathrm{c}$, frequency of visits per month, source of identification/ awareness of salon are interrelated to each other.

\section{Therefore,}

a. H11 hypothesis between gender and monthly expenditures on salons are inter related. (Some association (Cramer's V value is 0.040)).

b. H12 hypothesis between gender and frequency of visits per month are interrelated to each other. (Moderate substantial association (Cramer's V value is 0.131$)$ ).

c. H13 hypothesis between gender and source of identification/ awareness of salon are interrelated to each other. (fairly substantial Cramer's V value is 0.291$)$ ).

d. H14 hypothesis between gender and recommendation of hair salon are interrelated to each other. (Weak association (Cramer's V value is 0.027$)$ ).
And corresponding null hypothesis $\mathrm{H} 01, \mathrm{H} 02$ and $\mathrm{H} 03$ and $\mathrm{H}$ 04 are thereby rejected.

( Note: * Cramer $\mathrm{V}$ calculated values are used for test of association between nominal and nominal or ordinal values).

The facts drawn from this research implies that in future more detailed study of the hair salon industry can be pursued by inclusion of more samples and consideration of more factors. This results of this study can also be used by academicians, experts in beauty and hair salon industry and others which can further lead to systematization and prevalence of standardization, efficiency, growth and development simultaneously in concerned areas of relevance.

\section{SUGGESTIONS FOR HAIR SALONS}

Some of the possible suggestions for the growth of hair salons can be listed as follows:

1. Creating online salon seat booking facility with date, time, duration and other salon services details options available in the online booking form available in websites or apps in android smartphones.

2. By offering a free selfie station inside the salon, where customers can take selfies with new haircuts. This would encourage a new trend and customers would get confidence in hair styles adopted by them. They can also opt for unique changes in hair styles that can be customized based on their own perception of themselves through selfies.

3. Create unique 'Hair holidays' where joint packages for hair styles, nail cutting, hair coloring, threading etc. could be offered to customers through exciting price packages. These holiday packages could be promoted using online and offline medias. Special days such as valentine days, mother day, marriage seasons etc, could be great opportunities for such joint packages to be launched.

4. Hair salons can also sponsor local fashion shows. This can also lead to more advertisement for the hair salons that can actually lead to more customer attention for the hair salon brand. Also, event promotions must be adopted as a part of creating brand image and brand popularity and other brand related announcements.

5. Listing of hair salons in review websites can also generate more web traffic and attention of online customers searching for nearby, affordable and better rated hair salons. This can also help in online 
advertisements of the hair salons at cheaper costs with larger audience segment.

6. Popular websites, social medias such as Facebook, Insatgram, Pintrest can also generate a lot of followers who can be future potential customers among online audiences.

7. Generation of loyalty programs for loyal customers who visit hair salons on frequent basis can also help in customer referrals and more discount for such customers can actually draw more customers in future.

\section{REFERENCES}

[1]. Akter, S. (2008). The Business of Beauty. The Daily Star.

[2]. Akter, S. (2009). Personal Gets Revenue Glamour: Earnings Rise to Tk. 5.30 Crore. The Daily Star.

[3]. Cardozo, Richard N. 1965. "An Experimental Study of Consumer Effort, Expectation and Satisfaction." Journal of Marketing Research 2 (August): 244-249.

[4]. Gilmore, D.C., Beehr, T.A., \& Love, K.G. (1986). Effects of Applicant Sex, Applicant Physical Attractiveness, Type of Rater and Type of Job on Interview Decisions. Journal of Occupational Psychology, 59, 103-109.

[5]. Gupta, A., McDaniel, J. and Kanthi Herath, S. (2005), "Quality management in service firms: sustaining structures of total quality service", Managing Service Quality: An International Journal, Vol. 15 No. 4, pp. 389-402. https://doi.org/10.1108/09604520510606853.

[6]. Raheja, S. (2020) "Relevance of Integrity, Morality and Ethics in the Contemporary World: Learnings from Shrimad Bhagavad Gita", IARS' International Research Journal. Vic. Australia, 10(1). Available at: https://researth.iars.info/index.php/curie/article/view/107.

[7]. Kaur, A. (2014, August 12). International beauty salon brands buoyant on India expansion.

[8]. Kouthouris, C., \& Alexandris, K. (2005). Can Service Quality Predict Customer Satisfaction and Behavioral Intentions in the Sport Tourism Industry? An Application of the SERVQUAL Model in an Outdoors Setting. Journal of Sport Tourism, 10(2): 101-111.

[9]. Kumar, M., Tat Kee, F. and Taap Manshor, A. (2009), "Determining the relative importance of critical factors in delivering service quality of banks: An application of dominance analysis in SERVQUAL model", Managing Service Quality: An
International Journal, Vol. 19 No. 2, pp. 211-228. https://doi.org/10.1108/09604520910943198.

[10]. Mick, D. and Fournier, S. (1999)," Rediscovering Satisfaction", Journal of Marketing 63(4), 5.

[11]. Oliver, R. (1980), "A cognitive model of the Antecedents and consequences of satisfaction decisions" Journal of Marketing Research 17(4), 460.

[12]. Parasuraman, A., Zeithaml, V., \& Berry, L. (1985). A Conceptual Model of Service Quality and Its Implications for Future Research. Journal of Marketing, 49(4), 41-50. doi:10.2307/1251430.

[13]. Plank , S. , DeLuca , S. , \& Estacion , A. ( 2008 ). High school dropout and the role of career and technical education: A survival analysis of surviving high school . Sociology of Education , 81 , 345 - 370

[14]. Van der Wal, R., Pampallis, A. and Bond, C. (2002), "Service quality in a cellular telecommunications company: a South African experience", Managing Service Quality: An International Journal, Vol. 12 No. $5, \quad$ pp. 323-335. https://doi.org/10.1108/09604520210442119.

[15]. Wang, Y., Lo, H. \& Yang, Y. An Integrated Framework for Service Quality, Customer Value, Satisfaction: Evidence from China's Telecommunication Industry. Information Systems Frontiers 6, 325-340 (2004). https://doi.org/10.1023/B:ISFI.0000046375.72726.67

[16]. Winnie, W. (2005). Employment and the Law. Salon Business Solutions: The Professional Salon Business management Journal, 17,47-48.

[17]. Young, P. (2011). Facial Physical Attractiveness, Its Importance and How It Is Part of Our DNA. ArticlesBase.com. Retrieved from http://www.articlesbase.com/beautyarticles/facialphysical-attractiveness-its-importance-and-howit-ispart-of-our-dna-by-philipyoungmd-4377637.html

[18]. Zeithaml, V.A., \& Bitner, M.J. (2003). Services Marketing: Integrating Customer Focus Across the Firm. New York: McGraw-Hill.

[19]. Retrieved from https://krieger.jhu.edu/sociology/wpcontent/uploads/sites/28/2012/02/SOE-2008.pdf

[20]. Rao, E. and Goel, A. (2017) "Factors causing work related stress in the Hospitality Sector: A study of employees in three star hotels in Dehradun Region", IARS' International Research Journal. Vic. Australia, 7(1). Available at: https://researth.iars.info/index.php/curie/article/view/65 